\title{
Tradition, Rationalization, and Worth: Conflict over the value of artistic practice
}

\author{
working paper / draft 16.04 .02
}

\author{
Alison Gerber \\ Department of Social and Economic Geography \\ Uppsala University \\ alison.gerber@kultgeog.uu.se
}

\begin{abstract}
Situated in the juncture between professions literature and social scientific studies of worth and value, this article extends Zelizer's work on social processes of valuation and Boltanski and Thevenot's research on diverse orders of worth. Using interview, ethnographic, and archival data on visual artists, the author considers diverse accounts of the value of artistic practice and develops a model of social processes of disagreement about valuation in working life, processes of individual and collective revaluation of objects and practices about which there exists significant social agreement regarding value. The process consists of three stages: as traditional practices undergo an occupational turn, tensions between old and new orders of worth come to be expressed in conflicts over valuation; diverse accounts of value proliferate; and finally, some accounts - those that draw on contemporary visions of traditional practice-achieve widespread resonance and become widely shared meanings.
\end{abstract}

When traditional practice evolves into professional work, what effects do mismatches between the two structures have? This paper focuses on value and valuation as a potential site of friction between traditional and professional practice. Drawing on theoretical work on professions and valuation and a study of value in the visual arts, it shows how an imperfect rationalization of practice produces opportunities for conflict over value and allows for revaluations of professionalized work.

The practice of visual art is a rich source for those interested in value and valuation. The history of social scientific analysis in the visual arts has been one in which our collective attention has shifted from a strict interest in (cultural) values to a broader view that includes (economic) value. Contemporary research displays a central interest in price (Cowen and Tabarrok 2000; Fine 2003; Menger 2001), while sustaining a sense that pricing in the arts is ill 
captured by neoclassical economic theory (Karpik 2010; Velthuis 2005). Such lack of fit has fuelled critiques of commodification and models explaining constraints on it and modifications to circulation protocols (Kopytoff 1986; Wherry 2006). However, in its focus on art objects such research largely neglects artistic practice, and the assumption of a fundamental mismatch between market value and aesthetic value has led to a focus on problems of commodification that can just as well be understood as issues of valuation for the analyst less committed to a hostile worlds framework (Zelizer 2000). An approach that considers artistic practice as a whole - a field encompassing both wholly marketized and entirely noncommodified practices - both allows for a clearer image of historical and contemporary artistic practice and refigures questions of market value as questions about the appropriate valuation of practice rather than about the appropriate status of objects.

The history and evolution of modern occupational employment and its sometime development into professional work has long been of interest to social scientists. While practices that look much like modern jobs can be found in antiquity, contemporary sociological research on occupations and work tend, like Weber, to trace the shape of modern occupational employment to processes of bureaucratization and rationalization and to see working life as central to life in capitalism and to democratic participation (Goldberg 2007; Weber 2001). Professionalization one mode of occupational development - is of particular interest here. While research in the professions literature on other occupations are often concerned with the boundaries of the professional category (Abbott 1988; Brante 2011; Evetts 2003; Freidson 1986; Saks 2012; Wilensky 1964), much can be gained through the adoption of a professions lens to investigate a particular (apparently nonprofessional) occupational field's theory and practice. Rich and generative studies in the professions tradition include Larson's analysis of the political ramifications of new markets in professional services (Larson 1977), Spillman's investigation 
into the professional side of apparently nonprofessional work (Spillman 2012), Berman's study of the organizational and intraprofessional dynamics of professionalization processes (Berman 2006), and Timmermans's ethnography of professional authority and autonomy (Timmermans 2005). As will be discussed below, when traditional practice is occupationalized and then professionalized, the structure of professional practice is unlikely to match the structure of traditional practice. The double remove allows for multiple sites of conflict, and this conflict and the opportunities it engenders vis-à-vis valuation are of interest here.

There is a growing literature on the sociology of worth, value, and commensuration. This paper is situated squarely within a field of inquiry where we need not assume that economic value is different from, more important than, polluting of, or fatal to other forms of valuation. Zelizer showed us how we can price even what we claim as most priceless beginning forty years ago (for an overview, see Zelizer 2011) and since then other authors have investigated the interplay of money, morals, and meanings in arenas like the trade in human cadavers (Anteby 2010), sperm and eggs (Almeling 2007), and hearts (Healy 2004) in a stream of research that has shown, definitively, that the crass, blunt, mighty dollar need not supplant love, intimacy, or integrity. Rather than looking to lawlike models of pricing mechanisms, these researchers ask what prices tell us beyond a dollar value (Wherry 2008), how emotions influence economic life (Bandelj 2012), and whether market norms include reciprocity and redistribution (Spillman 1999). Economic sociology departs from economics by looking closely to the actual workings of economic life as social life.

This study engages in particular with the literature on commensuration - the unwieldy term used by economic sociologists to refer to the social processes by which multiple parties come to agree on value (Espeland and Stevens 1998). Imagine a scale - the old-fashioned twopan balance we use as the symbol for justice. Social studies of commensuration ask how we 
calibrate that scale, how we come to balance it, and why that point of balance varies so strongly by time and place. This article builds on recent work on social commensuration (Espeland and Sauder 2007; Espeland and Stevens 2008; Fourcade 2011; Huault and Rainelli-Weiss 2011) by aiming to articulate a process central to such valuations.

The richest site of overlap to date between the occupations and professions literatures and research on value and valuation has been the study of care work and gendered labor. Studies of what has traditionally been women's work, carried out as part of a household economy and without pay, have shown how unrecognized labor impacts well-being (Messias et al. 1997), asked how gender strategies influence household economies (Hochschild 2003), and have investigated when and how labor is legitimized as work (Daniels 1987). Some literature on "invisible work" draws on this tradition and carries it to less gendered arenas (Evans, Kunda, and Barley 2004; Fischl 2004; Star and Strauss 1999) but the literatures on professions and value only rarely cross. There remains a wealth of rich possibilities for investigation of this juncture.

This article looks to visual artists to consider whether and how professionalization impacts valuation in a community of practice (Wenger 1998). The practice of visual art is a rich source for those interested in value and valuation. The history of social scientific analysis in the visual arts has been one in which our collective attention has shifted from (cultural) values to (economic) value. Contemporary research displays a central interest in price (Cowen and Tabarrok 2000; Fine 2003; Menger 2001), while sustaining a sense that pricing in the arts is ill captured by neoclassical economic theory (Karpik 2010; Velthuis 2005). Such lack of fit has fuelled critiques of commodification and models explaining constraints on it and modifications to circulation protocols (Kopytoff 1986; Wherry 2006). However, in their focus on art objects they largely neglect artistic practice, and the assumption of a fundamental mismatch between market value and aesthetic value has led to a focus on problems of commodification that can just as well 
be understood as issues of valuation for the analyst less committed to a hostile worlds framework (Zelizer 2000). An approach that considers artistic practice as a whole - a field encompassing both wholly marketized and entirely noncommodified practices - both allows for a clearer image of historical and contemporary artistic practice and refigures questions of market value as questions about the appropriate valuation of practice rather than about the appropriate status of objects.

Despite the academic acceptance of a post-Zelizerian view that markets are not inherently in conflict with meanings and morals and lively investigation into the processes that allow us to make sense of markets, we continue to see resistance to economic commensuration - both to agreements made and to the validity of the dollar as final yardstick - in everyday life. Might we imagine, then, such resistance as something like a process? Is it possible that our attention to commensuration - agreement - and its qualities in surprising arenas may have led us to forget, ignore, or deny its opposite?

I will argue below that commensuration's opposite is not a simple lack of commensuration (what might be called "incommensuration"), but an active process - one of decommensuration. I refer not to Boltanski and Thévenot's "compromises", in which juxtapositions of diverse orders of worth are both temporary and fragile (Boltanski and Thévenot 2006), nor to Stark's “asset ambiguity,", in which flexible opportunists argue that first one, then another base of value is the one that counts (Stark 2009), though both processes are likely at play in the general case of contemporary artistic practice, and this study may contribute to the literature on heterarchy by suggesting pathways by which some organizing principles become salient to practitioners while others remain absent. The processes outlined below are not fragilein fact, I would argue that they are constitutive of a field of practice and as such are remarkably 
stable. Individuals tend strongly towards one or a few accounts of value, and use multiple accounts in patterned ways to do specific things.

This paper looks at what I will argue is commensuration's true opposite, a distinct process that is just as likely to lead to patterned and distinct processes and divergent outcomes as the processes of agreement we have grown to regard as central to understanding valuation. Such a process may be temporary or semipermanent, unchallenged or contentious, individual or subcultural. After so much attention to agreement, I turn here to disagreement. This paper draws especially on Boltanski and Thevenot's work on orders of worth (2006) but departs in two significant respects. First, in their work on diverse routes to valuation, distinct orders of worth can be brought to bear without regard to hierarchy. While there is no power in their constellation of orders, I take as a given that economic and market logics dominate in public life and especially in working life - that "everything has its price," and that, as the idiom suggests, we all know it. The process outlined below presupposes a socially dominant route to the valuation of practice and a will to renegotiate that valuation. In the process described here, the increasing power of market logic is central to the shift from traditional practice to occupational rationality. The transformation of a tradition to a profession involves many aspects - organized training and credentialing, increased bureaucratization and fit with state and institutional structures, the development of professional identities - all of which are deeply influenced by and understood in terms of a market order of worth. Second, if the types of accounts discussed above are conceptualized as distinct orders of worth, I question Boltanski and Thevenot's assertions regarding the inherent fragility of compromises between multiple orders, assertions based on notions of logical incoherence and the rules of public argument, in which to win one must not admit to nuance. I show instead how multiple orders of worth are engaged by actors simultaneously without issue and suggest that such relationships between multiple orders of 
worth can be constitutive of the field's landscape of practice. While distinct orders of worth might be logically incompatible, accords between them are not empirically untenable, and in fact some fields may be constructed so as to virtually require pairings and other groupings of diverse orders; 'compromises' are likely inherent to the system.

Below, I develop a model of social processes of disagreement about value in working life, a process of individual and collective revaluation of objects and practices about which there exists significant social agreement regarding value, using contemporary artistic practice as a case. Three stages animate the process. 1) As an extant, valued field of activity - a tradition - is rationalized and becomes understood as properly an occupation - a job, then a profession tensions between distinct orders of worth become salient for some practitioners and come to be expressed in conflicts over the valuation of practice. 2) Conflicts over the socially dominant valuation of practice take the form of diverse accounts of value and its bases by practitioners. In a context where occupational rationality and economic logic dominates, practitioners point to the limits of jobs when they insist on the inclusion of other bases of value. These conflicts take the form of distinct routes to valuation; they do not pit value against values, but aim to include some bases of value while excluding others. 3) Some bases of value and routes to valuation achieve widespread resonance and become widely shared meanings within the community of practice, while others fall away. The degree to which an account draws on and fits within contemporary visions of traditional practice predicts its level of recognition by others. This process is one in which conflict over appropriate orders of worth (Boltanski and Thévenot 2006; Heinich 1996; Stark 2009) is expressed in diverse and divergent valuations - a patterned, social process of disagreement about value and valuation.

Contemporary economic sociology can reproduce hostile-worlds ideologies when it treats commensuration to market value as surprising in the case of "special" or "unique" goods. This 
article attempts to remedy this blind spot by outlining a process that can be conceptualized as commensuration's opposite - an agentic process likely to vary across time and space and to lead to meaningfully distinct outcomes. I will argue that these remnants of not-yet-dead traditions create spaces of conflict where both old modes of valuation and new accounts of value can resonate and can become widely held, widespread meanings.

Drawing on data from a study of value in the arts, I propose a model that shows how tensions between orders of worth are managed by relevant practitioners and that traces the process by which resonant expressions become widely shared meanings. The distinct routes to valuation enabled by this process aim to include some bases of value while excluding others. Nor do they represent a nonsynchronism that hearkens only backward to an uncompleted past (Bloch and Ritter 1977); the revaluations discussed here exploit disjunctures as openings for new pathways to value as well as reaching back to traditional practice. The model proposed below allows us to see the patterns by which valuation in a community of practice is contested, highlights the importance of multiple pathways to value within fields, and shows how disparate valuations lead to divergent outcomes.

Methods

This article draws on data from three sources: 80 in-depth interviews and ethnographic fieldwork; archival and secondary sources on two artists' collectives; and oral histories of visual artists.

My first source of data comes from a study using interviews with visual artists and ethnographic fieldwork in four regionally defined art communities. I defined "artists" for this study with a proxy for artistic practice: the exhibition of artworks in public. Visual artists are 
defined for this project as individuals who have publicly exhibited visual artworks (drawing, painting, sculpture, photographs, and other forms commonly shown in institutions like museums of contemporary art) in the year prior to the interview. The sample draws on the sites at which art is shown and sold to the public: galleries, museums, art centers, and other presenting institutions. I chose a range of presenting institutions intended to capture variation in the types of presenting institutions currently active in the exhibition of visual art in the United States, representing different art worlds, with both geographic and urban/rural variation. These presenting institutions included, for example, a major contemporary art museum; an artist-run space; an airport; a church. For each presenting institution, I constructed a roster of artists who had exhibited artworks through the institution in the past year, and the roster was further narrowed to living artists currently residing in the United States. From this roster at each institution, I selected 5\%$10 \%$ of artists at random to contact for an interview. The sample represents diversity in occupational commitment and economic success in the fine arts, education, income level and type, gender, age, race, class background, and other dimensions.

My strategy in interviews was to ask questions that prompted respondents to tell me stories about concrete things that they have done and were doing. These data are drawn on below in the discussion of diverse accounts of value in contemporary practice; they are marked in the below analysis when artists are quoted using a first name only (a pseudonym). I have elected to, at times below, quote at length from the artists I have spoken with or discuss the setting of the interview, with the hope that richer data will allow the reader to see the actors in question as speaking actively and intentionally - even taking part in the creation of new meanings - rather than understanding them as empty vessels parroting only available meanings (Hennion 2014). A few of my interviews have happened in coffee shops or offices, and looked like what we might imagine when we hear the word "interview" - two speakers, interviewer and respondent, seated 
facing one another, a tape recorder between; at the end, a handshake. But many more of the interviews happened in people's homes and studios, have involved something more. I have stayed with interview subjects, eaten meals with them, met their partners and their children. I have cooked food for some; others have slept on my couch. Some I have spoken with once; others I am in touch with regularly; a few are now friends. All of this has served as sources of data that have contributed to this study.

Two sources of data are considered below in the discussion of historical processes. The first source involves archival materials relating to two loose coalitions of artist-activists engaged in conversations about artists' labor, work, and remuneration. The Art Workers Coalition (AWC) was a short-lived but well-documented collective of artists active from approximately 1967 through 1971; Working Artists and the Greater Economy (WAGE) is a similar group active since 2008. While the AWC never developed a formal organizational structure and dissolved entirely by about 1971, WAGE recently moved to a nonprofit model, though its original members are now loosely affiliated if at all. These two groups are considered here as case studies of collectives that aim to speak to and for artists, and it is the content of that speech that is of interest here.

The second source of historical data is a database of 911 oral histories with visual artists drawn from archives at the Smithsonian Archives of American Art (all transcribed interviews available from the archive). These data were intended to complement the above data on the AWC and WAGE and to serve as a bridge between that data and my own interview data, which informs the bulk of the paper. The oral histories in the database include interviews dating from the 1950s and later, and here I draw on two subsets in particular: first, artists born in the 1930s and interviewed during the 1960 s and 70s; these artists were born in the same decade as the majority of those recorded as speaking to and for the AWC, and were interviewed during the rise and fall of that collective. A second subset of artists born after 1960 and interviewed after 2000 are 
intended to be comparable both with those who are recorded as speaking for WAGE and those younger artists I have interviewed. The comparative structure in the historical discussion below, then, is a $\mathrm{T}_{1} / \mathrm{T}_{2}$ comparison, with $\mathrm{T}_{1}$ data consisting of $\mathrm{AWC}$ documents and oral histories from artists born in the 1930s who were interviewed during the $60 \mathrm{~s}$ and $70 \mathrm{~s}$, and $\mathrm{T}_{2}$ data including WAGE documents, oral histories from artists born after 1960 and interviewed after 2000, and my own interviews and ethnographic work (2008 and later). Analyses from archival sources are drawn on in the discussions of diachronic processes below, while my own interviews provide the basis for the synchronic processes I outline.

From tradition to occupation and profession

The first stage of the processes of conflict over value in working life outlined here concerns a perceived conflict between traditional and contemporary practice. As an extant field of activity is rationalized and becomes understood as properly a profession, tensions between distinct orders of worth become salient for practitioners and come to be expressed in conflicts over the valuation of practice.

The visual arts as a field encompassed a wide range of socially and economically valued practices before visual arts practice became rationalized in the last century into an occupation. Artistic practices - the production of "artworks" as well as other forms of creative practice, such as decorative and folk art practices - had nonmarket value, especially evident in the private sphere, as well as market value in the public sphere; artists could make a living through commissioned work, patronage, or sales. A wide variety of individuals engaged in artistic practice, from those who learned their craft at home and worked exclusively in home production to "fine" artists who engaged in long apprenticeships, copying the work of their masters until 
their reproductions were gauged appropriately authentic. While the apprenticeship model and, later, the academy model gathered strength by the $19^{\text {th }}$ century, even those who hoped to make a living as artists followed no set path, and well into the $20^{\text {th }}$ century the notion of artistic practice as a “job” was rare (Gordon 2006; Kemp 1997; Montias 1989; Vasari 1987; White and White 1965; Wittkower and Wittkower 2007). The changes I outline below are not, as we might imagine, a change from autonomous, private practice to market work. Artists have engaged with the market in ways that mirror some contemporary practices for centuries. The change I outline below is, rather, a story of rationalization and professionalization, of artists first looking at their practice as a modern job, then a modern profession.

As late as 1969, artists speaking on behalf of their colleagues could still insist that artists were not workers:

\footnotetext{
"The name of the group heretofore named the art workers' coalition has been changed to artists' coalition. This is done $[\ldots]$ because artists are not workers; because all persons who regard themselves as artists are artists, no matter what their activities..." (Art Workers Coalition 1969:102-110)
}

While the group is remembered today as the Art Workers Coalition, it is clear that in 1969 the notion of the art worker, of art as a job, was not yet widely held. In comparison, by 2008, artists like those speaking as WAGE had re-conceptualized artistic activity as a form of labor: "Artmaking is labor. Art-making is my job." (Steiner 2008). In short, making art had become work:

We're not asking for the world, we are asking simply to be paid for our labor. Museums want performance art for free? What do they think? That we dream it up while we are 
watching TV during the commercials? That's work. That's days, or weeks or months of work [...] We need our city's institutions, public and private, to take artists' labor into consideration when using it. We need to let them know that what is making their culture institution "rich" is the product of months or years of labor. (Hardy 2008)

Bryan-Wilson traces the emergence of the "art worker" to the 1960s in the United States. While she focuses on aesthetic change, she also argues that the identity of the art worker was necessary for artists to claim a stable social position and a platform from which to assert political identities (Bryan-Wilson 2009). The notion of the "art worker" was visible but not widespread in the 1960s and 70s; the rationalization of artistic practice was underway, but had not yet been embraced by all practitioners. Evidence for this can be found in variation in artists' narratives about their practices in the 1960s-1970s compared to those speaking after 2000, particularly as they relate to two topics: 1) the centrality vs the peripherality of the sale of objects, and 2) the development of professionalism in the fine arts. In both of these arenas, artists can be seen discursively and symbolically to move from a vision of artmaking that aligns with traditional practice to an understanding of artmaking that is occupational and highly professionalized.

The sale of objects, at the center of making a living as an artist in the 60 s and 70 s and in the centuries before, is demoted both instrumentally and morally by the 2000s. In the Archives of American Art corpus interviewees in the 60s and 70s spend remarkably little time on the specifics and meaning of artist-dealer relationships, prices, or other features of making a living selling art. When the topic is discussed, it is in a perfunctory fashion, as it is already understood between interviewers and artists alike that there is one path to a career in the arts: the production and sale of objects, preferably through a prestigious gallery and at a healthy but not exorbitant profit (e.g. Conner 1974). In the 1960 s and 70s teaching and other pathways to financial solvency are 
untenable in the minds of most artists. While some teaching positions did exist, in the $60 \mathrm{~s}$ and $70 \mathrm{~s}$ artist-teachers were failures, engaged in wage labor for art-adjacent activities rather than being 'real' artists (e.g. Clarke 1972). By the 2000s the notion of the artist-teacher as less serious or "real" that was so common among artists speaking in the 60 s and 70s has nearly disappeared. One reason for this change can be seen to populate interviews with these younger artists: in the 60 s and 70s teaching artists, if they were remembered by their students, were remembered as great teachers, while by the 2000 s visual artists with unimpeachable reputations as artists populate the art academies these younger artists attended - especially if they attended the most elite institutions (e.g. Wiley 2010). In my interviews as well young artists regularly speak of their professors as artists, not as failed artists or as teachers - in stark contrast to those speaking in the 60s and 70s.

By the 2000s, there are many legitimate pathways to a remunerative life in the arts, and significant inequalities in the art world mean that one cannot assume much about those who report a relationship with a gallery (Graw 2010). Oral historians today inquire with some depth, and artists readily speak at length, about the particularities of commercial practice, while today it is other pathways to financial solvency that are treated as unworthy of comment: teaching, grantwriting, and public projects are all assumed to be poorly but passably remunerative. For the 2000s wave of artists, object making and sales is no longer the default way to make a living. It is still a path, but now a raised and highly visible one, a sort of boardwalk that requires a bit of buttressing; moral and political concerns seem also to require a bit of performance about the walk's narrow path, its pitfalls and rotted planks.

Emma Amos (b. 1938, interviewed 1968), one of a few who spoke at length in the sixties and seventies about her sales career, talked about how difficult it was for her to make things that wouldn't sell, preferring instead to focus on those things she had found a market for. She spent 
the majority of her time working with printmaking, the remunerative side of her practice, though she also made work in other media:

The thing that influences my work most is what am I going to do with it. [...] if you have no outlet to sell it then sort of what's the point in doing it? [...] I get a few little checks sometimes dwindling in every month or so from this being sold or that being sold and it makes me feel good and it pushes me on to doing more work in printmaking. (Amos 1968:n.p.)

Kehinde Wiley (b. 1977, interviewed 2010), by comparison, went to great lengths to simultaneously embrace and reject an object orientation. He said straightforwardly of his work, "These are high-priced luxury goods for wealthy consumers." In the logic of selling art as the primary activity in which he engaged, Wiley even talks about himself reflexively as an object, saying that he's "working towards expanding [...] the Kehinde Wiley brand". He explained his choice of words by pointing to the "reality of the fact that artists now exist in a society that is really driven by consumer culture.” (Wiley 2010:n.p.) His up-front acknowledgement of the inequalities of the art market is common among artists who are a part of it, as are his politicallytinged words. Franco Mondini-Ruiz (b.1961, interviewed 2004) was equally straightforward when he talked about the market and its drawbacks. He talked about prestigious galleries, including his own:

They want prestige and a good reputation, and it's a game. It's all an illusion. You know, nothing has value innately, except food and water and air [...] I am attracted and repulsed at the artificiality and the elitism of it, and the artifice of it. [...] that's snobbery. That's 
just buying expensive knick-knacks - to me. That's how I see it. And I'm part of the snobbery game because I'm an object-maker and I make knick-knacks for the rich and I don't want to do that. (Mondini-Ruiz 2004:n.p.)

Mondini-Ruiz had been poor and rich and back again, and had settled into a very contemporary practice and view of his place in the high art world. He applied regularly for grants and demanded high fees to produce his work from museums and other art institutions. He sold work both through a prestigious gallery and on the street for five dollars. He had moved to a new strategy, selling paintings himself for \$99 each:

And paintings, I sell for $\$ 99$ each [...] as far as making a living on art, I want to do it in a more socialist way and this is going to be my formula. I might lose my gallery. But right now, she is going to allow me to do a four-day show in New York. She is embarrassed about it but I'm going to sell 300 paintings for $\$ 99$ each. [...] I want to just have this business that - it's very democratic and I make work that's very affordable, and worth my while and makes people happy, and I don't have to depend on the white elite to give my life meaning, you know? (Mondini-Ruiz 2004:n.p.)

Mondini-Ruiz loved making these paintings and selling them cheaply: Still, selling has a tinge of filthy lucre, and in order to justify his interest in it he reached back to the particularities of his past. He grew up working-class, then middle-class with parents who owned a few electronics stores: “don't forget I come from- we are peddlers, you know, and I love selling things.” When his interviewer asked about sales, he reached back to the past again: "I got that from my mother, a kind of a gypsy way of wanting - loving the cash, just loving the cash, touching it and counting 
it. I didn't even know what I wanted to do with it.” (Mondini-Ruiz 2004:n.p.) The sale of objects after 2000 requires, for most artists, an excuse, an explanation, and a specific relationship to capitalism and value - all things that an artist speaking in the 60 s and 70 s could take for granted, given that there few other options for an artist to both make an income and remain a legitimate artist, rather than really a hobbyist or really a teacher of art.

Singerman (1999) points to the growth of university-based professional schools as crucial to the development of the professional identity for artists, and with it the decline of sales as the singular path through which artists may receive compensation for their work. Oral histories and my own interviews support his thesis; over time, increasing numbers of those practicing as visual artists a) attend degree-granting programs at the bachelor's level, b) attend such programs in university settings, and c) obtain master of fine arts degrees. As late as the 1960s and 70s artists who attended independent art academies were not guaranteed any kind of academic degree (e.g. Remington 1973), and relatively few attended masters' or PhD programs in arts practice. Today art students are nearly always granted college credit and associates', bachelors', and masters' degrees, and most universities provide at least degrees at the bachelors' level in the fine arts. (Singerman 1999:6). Artistic practice today has undergone an occupational turn, with artists today experiencing their artistic practice as "serious" "work", a "job", a "profession" (Bain 2005) - this despite the minority of artists who make a living at art work.

A professionalization is reflected in oral histories from the past fifty years in the ways that artists represent their "day jobs", their employment outside of their fine arts practice. Two differences between interviews forty and fifty years ago and those carried out today are apparent: first, while those interviewed in the 60s and 70s spoke primarily of blue-collar and entry-level work, younger artists interviewed after 2000 talked in the main about professional work outside of their arts practice. Second, while artists used to speak dismissively of the work they did 
outside of their artistic practice, artists today are likely to discursively incorporate their "day jobs" into their artistic practice, as part of the package of activities that one "naturally" engages in as a professional artist.

Robert Ryman (b. 1930) was interviewed by the Archives in 1972. His interviewer asked how he made a living before he could live off of his art, and they talked about getting by “flunky job after flunky job," eight years of work as a messenger, gallery guard, library manager. Ryman laughed, and asked the interviewer - "I mean, is anyone interested in that?" He said he “didn't want any kind of job with any real responsibility, because that would have been the end of everything." (Ryman 1972:n.p.) Like others interviewed at around the same time, such discussions of getting by immediately dropped off once it was understood that Ryman began to make a living by selling work - such activity is the basic assumption, the details of it easy to skate over.

By comparison, when Kristina Faragher (b. 1961, interviewed 2002) spoke of dedicating her life to art, to her "decision to pursue art as my only career", she was not talking about making and selling objects. Making a living as an artist today can mean many things: the pursual of grants, teaching, running a small business, and other activities outside of the production and sale of objects. For Faragher getting by as an artist included modeling. She recast her job as an artists'model in aesthetic terms, as part of her practice, as artwork itself. She told her interviewer that as a model she "contributes" to completed work with her "vulnerability," collaborates with the artists that draw her: "artist and model are engaged in one activity. In other words [...] I am drawing but I am also being drawn.” (Faragher 2002:n.p.). Something that might be simply a "day job" is recast as an element of her practice. Others interviewed in the recent past spoke of professional work done as a "day job" - work as a corporate lawyer, for example - as not only not detracting from but as contributing to their artistic practice (Mondini-Ruiz 2004:n.p.). 
Artists today rarely claim that their day jobs are "just" jobs, unconnected to their artistic practice. They are likely to aim for white-collar and professional jobs as "day jobs" rather than the entry-level and blue-collar jobs artists in the 60s and 70s saw as their only options. They see these professional jobs as their right - they see themselves as professionals, enact professional status, and are often highly educated and skilled. Though artists in the 60s and 70s often had the same education and training, they did not usually see themselves as artist-professionals, and rarely saw professional work as either open to them or as plausibly allowing for an artistic career. Artists today are likely to have specialized training from a university or professional school, and full participation in most art worlds, especially high-status art worlds, requires at the minimum a professional pose. Today - in sharp contrast to even fifty years ago - artists are required to present themselves as "full-time," "working" artists.

This rationalized, occupational vision of the proper role and position of the artist now dominates, in a field that retains meaningful remnants of a quite different vision of artistic practice - including living artists whose practices and expectations were first developed in a very different landscape. My own interviews with artists reflect this new, highly occupationalized vision of artistic practice. Few artists refer to themselves as hobbyists or amateurs, whether or not they are seen by others as working or professional artists. All of the younger artists I interviewed positioned themselves as "serious", "professional", "working" artists, in line with the demands of an occupationalized landscape of artistic practice. Many explicitly differentiated themselves from amateurs, nearly spitting at the word: Amy told me, "I have a mortgage, I have a kid. I can't have a hobby." While each element of art-as-a-job occasionally comes under wide scrutiny in concerns over the value of an MFA or discussions about the relevance of a forty-hour work week, and artists as workers pose significant problems for labor market researchers, especially when professional status is assumed to be a stable independent variable (Lena and Lindemann 2014; 
Menger 2001), within the field of the arts conflict over individual elements of rationalized, occupational artistic practice pales in comparison to conflicts over value in the arts. It is here, in tensions between varied bases of value and forms of valuation, that the imprecise fit between a well-developed traditional practice and newly rationalized occupational and professional practice is most clearly visible. In contemporary art worlds, tensions between traditional practice and the demands of full-time, occupational commitments to the arts are visible everywhere.

Diverse accounts of value, distinct routes to valuation

In the second stage of the process under consideration here, conflicts over the valuation of practice take the form of diverse accounts of value and its bases by practitioners. These conflicts take the form of distinct routes to valuation. Accounts of diverse and divergent valuations appear as individuals engage in conflict over the appropriate valuation of artistic practice. Below, I draw on in-depth interviews with artists to investigate the types of accounts widespread among contemporary visual artists in the United States.

I find four different types of accounts to be widespread: 1) pecuniary accounts; 2) credentialing accounts; 3) vocationalist accounts; and 4) relational accounts (see Table 1). Both pecuniary and credentialing accounts fit rationalized understanding of valuation in jobs as well as our historical imagination about income generation in the arts before, say, 1900; I will consider these in brief, before moving on to a discussion of the arguments implied by vocationalist and relational accounts.

\begin{tabular}{|c|c|c|c|c|}
\hline & Pecuniary & Credentialing & Vocationalist & Relational \\
\hline Time & short-term & long-term & suspended & generational \\
\hline
\end{tabular}




$\begin{array}{lllll} & \begin{array}{l}\text { specific } \\ \text { clock time }\end{array} & \begin{array}{l}\text { uncertain } \\ \text { clock time }\end{array} & \begin{array}{l}\text { transcendent } \\ \text { task oriented }\end{array} & \begin{array}{l}\text { transcendent } \\ \text { task oriented }\end{array} \\ \text { Justifications } & \begin{array}{l}\text { numerically and } \\ \text { univocally } \\ \text { calculative }\end{array} & \begin{array}{l}\text { non-numerically, } \\ \text { univocally } \\ \text { calculative }\end{array} & \begin{array}{l}\text { multivocally } \\ \text { calculative }\end{array} & \begin{array}{l}\text { multivocally } \\ \text { calculative }\end{array} \\ \begin{array}{l}\text { Institutional } \\ \text { Foundations }\end{array} & \text { Market } & \text { market } & \text { religion } & \text { state }\end{array}$

In pecuniary accounts, the time implied between investment and return is relatively shortterm and specific. "Clock time", with its attendant busyness and density (Snyder 2013), structures accounts. Artists regularly use numerical justifications and make on-the-fly calculations in the process of accounting for investments in pecuniary accounts. Such calculations are widely understood as legible outside the field of art, and fit Weber's image of instrumental rationality (Weber 1978). These accounts are oriented to a commodity market - a market that trades in art objects. The logic of this commodity market dominates pecuniary accounts, such that when artists use pecuniary accounts they often fit ephemeral and nontraditional practices to such a logic they speak of performances as "objects," for example. The ideal artwork in these accounts is defined by its salable quality, and the ideal space of such accounts is the commercial art gallery. Pecuniary accounts are deeply grounded in art worlds, and as such their orientation to the public is only partial.

Straightforward pecuniary investments and returns are, for artists, easiest to discuss, easiest to calculate, and easiest for outsiders to understand. I asked Josh whether he considers his finances when he makes new work, and he answered quickly:

"Yeah, I'm using some liquid to just kind of deal with things, but yeah, totally, I always have, I always have. Even when I was borrowing money from the bank to make 
work, and factoring how I would pay it back and the math that would be required in order to pay it back... doing math like, this photo is going to cost $\$ 25,000$ to make. And it will be an edition of five, and each one will sell for $\$ 15,000$, which means that I will make $\$ 7,500$ for each. Which means that $\$ 7,500$ times five is the total income, less the investment of $\$ 25,000$, equals this. So in my head, yes."

Josh's narrative, with its calculative clarity and rational tone, is representative of many who use pecuniary accounts, as was its connection to the sale of an object. Sales and, in particular, the sale of paintings dominate pecuniary accounts - even appearing in accounts among some artists who do not use the medium. Making paintings specifically to earn money, even by those who do not focus on painting in their "own work", is a possibility widely acknowledged among artists. Adam, who today does not paint or even draw, told me he painted to earn money when he needed college tuition:

I had to be very conscious of how to survive. And so weirdly, actually, I started making paintings in college to pay for college. It was a private school and I had no financial assistance from my family. And so there were rich kids there. Some of whose parents were patrons. The school itself would buy paintings for me. Like the administrative departments, to decorate.

Pecuniary accounts can be used to narrate other, less object-oriented practices as well. Gregory told me about a shift away from painting and sales driven primarily by financial insecurity:

I changed my artistic practice and I started doing performances because as a performer you get a fee. And it's different because when you're making paintings, you put all the 
money into the production of it, and then you're sort of hoping that this other person helps to sell it, and then you wait for them to clear the check, and then it comes back to you. So performance was the better way to go... I started that project and in fact it was successful in its goal. I get invited by schools and nonprofits and different kinds of, all different, you know, the project works anywhere really... the performance thing is really what saved me, as being, continuing to be in conversation with these other artists, because I didn't have studio space, I couldn't afford to make artwork.

Note Gregory's statement of the project's “goal” - to be invited to perform, for a fee. Such pecuniary accounting is visible in many artists' narratives, and clearly translate well to an occupational vision of artistic practice. But such straightforward accounts are only one way to account for investment in artistic practice by pointing towards a calculable potential for income.

Credentialing accounts share some features with pecuniary accounts: they, too, are structured by clock time, are legible outside of the field of art, and are highly grounded in art worlds, with only a minimal orientation to the public. However, credentialing accounts deviate from pecuniary accounts in a number of ways. The time implied between investment and return is long-term and uncertain, and while calculations abound, numerical justifications are not used. These accounts are oriented to a labor market, where skills have value; as such, they straddle the line between instrumental and value-rational logics, between working for income and occupation as identity. The ideal artwork in credentialing accounts is defined by its technical superiority, and the ideal space of these accounts is the art academy.

A number of artistic careers - in teaching and commercial work, for example - either require independent artistic practice or are enhanced by it. In contemporary practice, this is most visible in artists' discussions of teaching and commercial work. Teaching art to adults more or 
less requires documentation of an active and independent artistic practice, and at the highest levels, artistic practice as credential outstrips all others. Sophie told me that as she was only a few years out of graduate school, she wasn't ready to look for teaching work: "I would like to teach... I feel like maybe in five years I could find a teaching job but right now... they're like, 'What's your exhibition history?"”. Many types of employment - both in and outside the art world - are open to artists, and artists regularly translate skills developed in their artistic practice into paid employment. Adonis has worked as an assistant to another artist for some time. His background is in sculpture, while his employer's is in painting, and it was his artistic practice that got him the job. At the time of our interview, he worked 32 hours a week:

There is a lot of research and development... I engineer all of the things that get made there, so all of the troubleshooting, problem solving, learning how to work with plastics and foams and things like that, that's all my job.

Synnove works as a librarian, a job she got thanks to skills she developed working with photographs. She pulled out an invitation card she had finished recently and told me about the design process, then shifted to talking about her day job: "This has driven me to improve my computer skills, so I'm more employable. That's one reason I was able to get a technical job, which I shouldn't have. I'm obviously not qualified as a librarian." Carlton developed skills through his art practice, originally film- and video-based, and used them to occupy a strange and well-remunerated niche: "My jobs were doing 16mm loopers for museums. That was something that I just found out that nobody knew how to do really, or not that many people could do it. So that was a really good supplement." 
In pecuniary and credentialing accounts we see artists entering the world of market work and paid employment as artists in ways that both make sense to artists (who have for centuries sold artworks, taught others, and applied their skills outside of art worlds) and in a world of jobs, in which selling one's products, skills, and time by the hour or by the piece are normal ways to calculate worth and value (Biernacki 1995).

Other accounts of value widespread among visual artists are more difficult to fit to occupational practice and its valuation, but have strong relationships back to historical imaginaries of traditional practice and traditional values and valuation. As we will see below, this does not imply that they are old meanings; in fact, one of the types of account discussed below reaches back, while the other reaches forward and promotes a new pathway to valuation - but both draw on historical imaginaries for their legitimacy. The two routes discussed below are highlighted by artists as they engage in conflict over valuation. Through such accounts of value, they insist on the importance of diverse orders of worth and attempt to renegotiate the value of artistic practice.

Vocationalist accounts differ strongly from either pecuniary or credentialing accounts. Time is irrelevant to narratives of investment and return; it is suspended, transcendent, and has much more in common with the task oriented time described by Thompson (1967), including its lack of division between "work" and "life", than with modern, regulated clock time. Numerical and calculative justifications do not appear in these accounts. While the practices discussed in these accounts are relevant to the labor market, the accounts are not oriented to the labor market, and in part thanks to this they are largely illegible to those outside the field as legitimate explanations of investments. These accounts can be categorized as value rational narratives, with institutional foundations (however distant) in religion (Rosso, Dekas, and Wrzesniewski 2010; Wrzesniewski et al. 1997) and the ideal space of such accounts is the home studio - domestic, but 
set apart from everyday life. There is no ideal artwork in vocational accounts. In fact, the outcome of artistic practice is often minimized as irrelevant. Unlike the other types of account considered here, the art world is not basis for action in these accounts, and the self is the only relevant actor. Vocationalist accounts of investment and return have no public orientation, nor do they point directly to any art worlds.

Elaine is a photographer, choreographer, and dancer. For twenty years, her day job was in accounting, but at the time of our interview, thanks to a prestigious fellowship awarded as a lump sum, she had been able to leave her job and focus only on her work. I asked her about the ins and outs of mounting a performance, and her calculating self, armed with the newest version of Excel, shone through as she told me about the costs of the work - though always with an undercurrent of something else:

Last summer I did a show at the Winter Theatre, and that was a commission. So they paid me to do that, I got two thousand dollars. The lighting technician came with it, so I didn't have to hire a lighting designer. We pretty much promoted the whole show ourselves. We had to pay for postcard design, I took the photos, I didn't have to pay a photographer, but thank God for things like Facebook and e-mail, which is, other than your time, a cheap and free way of presenting your stuff. I pay people, everybody, paid them the same wage, ten bucks an hour for rehearsal, and then I had to also rent a rehearsal space, which luckily I have a friend who has a studio that he lets me rent for really cheap, he rented it to me for five dollars an hour. I kept this big spreadsheet of each rehearsal, who was there, kept track of how much they were gonna get, and just kept a running tally. [...] I pretty much did all of the costumes, either out of my own stuff or sourcing stuff myself. So didn't spend a whole lot on costumes. Then I just paid everybody their hourly wage. And 
right before you have a show there's a long tech week where you're in the theater a lot and I paid everybody their hourly wage for that.

Pecuniary logics clearly structure this narrative - witness the easy use of numbers and the many references to calculations (even, here, unusually, to a spreadsheet), the clear references to clock time, to rental costs and wages calculated by the hour. But there's always something else, something more. We continued to talk about the project, and it became clear that vocationalist demands altered Elaine's calculations away from a strict bread-and-butter accounting. Her goal, as we shall see, was not to come out ahead or even to break even on the performance, but to complete the work, and to complete it with her ethics and vision intact. She said of the $\$ 2000$ she was paid: "That sounds like a lot of money, but ultimately it was less than half of what I ended up spending on it." She went on: when she told me about paying her dancers, it was apparent both that if she wanted to come in under budget she could have planned the piece differently, and that her hourly rate is set through a mix of ethical and financial pressures:

I, for whatever reason, ended up working with a huge cast. I had worked with three people for a long time, and so that involves... not everybody does it this way but, um, in an ideal world, you pay your performers for rehearsals. I can’t speak for theater or for other choreographers but, it's really, it's a nice, you want to do that. That's the right thing to do, is pay people for... and usually you just pay an hourly wage, so I pay people ten bucks an hour which, in the real world, is nothing, but... unfortunately for dance, around here, that seems to be sort of average, or on the higher side, which is [she laughs] unfortunate. I paid myself an hourly wage for rehearsal but that doesn't even touch on, I didn't keep track of preparatory time, which is lame, I should've done that. So, over that, not counting the choreographic fee, I think I went over budget by, like, $\$ 2500$, probably. 
When Elaine told me about these decisions, her voice was no longer the confident tone of the accountant; she hemmed and hawed, nodded to the absurdities of some of her choices, laughed at herself. Things simply happened, "for whatever reason". She acknowledged a crucial point only in passing - when she said that she "didn't keep track of preparatory time" and said that she went over the budget even "not counting the choreographic fee," what she meant was that drawing an income from the commission was her lowest priority. She spent the commission she was awarded and then spent out of pocket to create the work she envisioned, one where aesthetic demands took priority and ethical concerns drove a significant part of the budget. But she did not keep track of or prioritize her own pay - by any calculation what should have been by far the largest cost of producing the work, since she acted as the creator, choreographer, director, videographer, and producer of the project. Not including these significant but unaccounted for costs, she personally came out of the project very pleased and $\$ 2500$ in the hole.

Elaine interweaves pecuniary and vocational accounts within one narrative, and this interplay between the two types of accounts is central to her accounts of the process of coming to make the decisions that she did. Occasionally she nodded to apparent conflicts between the two types of account, but did not accept such a conflict as insurmountable - rather, the push-pull of pecuniary and vocational accounts are central to her understanding of this practice as "her work". Making a living isn't the only way Elaine makes sense of her career; other values interact with the pecuniary. Elaine and other artists use pecuniary and vocationalist accounts in concert to position themselves, their practices, and their works as both serious and called - as doing it both for love and for money.

Many artists find returns in the autonomy, integrity, and tolerance for specificity that an artistic practice can allow. They acknowledge the hard work and sacrifices of artmaking, but 
consider the work fundamentally rewarding - and often argue that such rewarding work is in itself repayment enough for the resources committed to their practices. These artists account for investments by pointing to the incredibly high value of meaningful work - a value acknowledged as central in most occupations (Bunderson and Thompson 2009; Wrzesniewski and Dutton 2001) and occasionally accounted for by cultural economists (Caves 2003). Artists regularly offer horror stories of the indignities of 'regular' employment. These artists did not generally live outside of the world of paid work or sales, but used these stories to show by counterpoint the value of an artistic practice (for a discussion of a similar process in another field, see Plummer 2002). Kerry, who had worked in a wide range of jobs, some for a number of years, before moving to full-time work in the arts, emphasized his short-lived career as a barista when I asked about his employment history:

“I was at Starbucks for a day before I was like, I can’t do this. I just, I can't, I can't do this. And it was still in the middle of the training. They were making us taste coffee. And they were trying to get us to talk about coffee in the proper way and everything. They asked me to taste a cup of coffee and I tasted it and I was like, 'Oh my God, this tastes like dirt.' And the lady's like, "You... no. Don't tell the customers their coffee tastes like dirt.' I'm like, 'No, it tastes like dirt, I'm sorry, it tastes like dirt.' She says, 'No, no, no. You say it's earthy, it tastes earthy.' Like, ok, fine, you call it that if you want to. But I'm going to call it dirt. And so, after that, I left at lunch, and I was like, I'm not going to do this. This is ridiculous."

In his narrative we see hints of the themes that recurred in my discussions with artists: market work often disallows the integrity and autonomy that artistic practice encourages; market work is 
often incompatible with artists' self-identity; and market work, beholden to forces alien to the individual, often disallows the specificity, depth, and accomplishment possible in artistic practice. Armando neatly summarized a common sentiment: "When I say time for myself I mean time for my work."

Artists account for investments in their practice using vocational forms when they point to returns involving the ways that artistic practice can allow for the meaningful work that they see as uncommon or impossible in other employment. As a group they tend to find the notion of 'working for the weekend' laughable, and nearly without exception they find that autonomous work in keeping with one's sense of self, done with integrity, on a subject of one's own choosing and to one's own standards, is its own reward.

Relational accounts share some features with vocationalist accounts, and like vocationalist accounts they depart in significant ways from both pecuniary and credentialing accounts.

In 2012 I visited Alan at his home in a large city on the West Coast. Inside it was clean, white, spare, very bright. We went back to his kitchen to sit and Alan poured me some coffee. We talked for a good while before I turned on my recorder, finding mutual acquaintances. I asked him what work was like for him when he moved to the area, and he grimaced:

I felt like it took a while to get accepted into a circle. And a couple of people were way more welcoming. I started more in-depth friendships with them. And making stuff and talking with them more. [...] by being generous with others, and creating opportunities for other people that I wanted to work with, that I thought they were making fun stuff, or I thought they were being generous in other ways with other people, those were the people I wanted to work with. 
When he told me about projects he had done and people he had met, he always focused on the close relationships he formed - not the networking, or the events he had been a part of, the art he had made or his sales or fees, but the friendships. He told me someone saw his videos, and liked them; the result: "that started some friendships and stuff." He did a project with artists in another city, and situated it art historically in relationships: "It's kind of like these early versions of performance artists of the '70s, going down there and coming up here and having exchanges. There's a real warmness in the people." In his artwork he aims most often at sites far outside of galleries - he does work on the street, in public, in a children's museum. I asked about a longterm project he was engaged with that involved other artists. He told me it was relationships that counted: "It's trying to work with somebody I want to spend more time with, or talk with, and stuff, instead of it being just like, 'I need to do a show,' It's like, no. I don't need to do a show." We talked about his life in and out of art institutions, and he told me why he kept one foot in the door, why he continued to work with traditional institutions though so much of his work - and so much of where he finds meaning - is outside:

Do you want to make a living from your work or do you want to make a contribution? I keep... I think just that word, "contribution," is something that keeps coming back to me. I think reaching out cross-generationally to artists of the area or outside this area and having more extended conversations with them and befriending them and having more indepth conversations with them... it's not just being written about in a book, it's about being... "camaraderie" is maybe a better word for what I'm kind of after. The people that you admire or really appreciate in terms of what they've done with their work, you're a part of that conversation and you're part of that kind of extension and they understand what you're up to more than other people will. 
After the taped interview we talked some more, about all kinds of things. Eventually I had to leave, and he walked me to the door, barefoot, and followed me out onto the street. A neighbor's mail has been delivered to him accidentally, and he wanted to get it back to them. We lingered on the street, talking a while, and then I left.

Relational accounts of investment and return transcend clock time, displaying instead both task-oriented and generational understandings of time. Numerical and calculative justifications do not appear, and in these value-rational accounts the relevant market is unclear, though the institutional foundation is not - in relational accounts, the presence and structure of the liberal state is often apparent (Polanyi 2001). These accounts are rarely legible as explanations for investments to those outside the field, though like vocational accounts they involve widely shared meanings within the field of art and are readily understood there. They are strongly rooted in art worlds but oriented to a wide public; the ideal space for these accounts is public space, and the ideal artwork is one that sparks public debate.

Relational accounts point to a belief among artists that their practices are, at the very least, good for society and, at best, transformational. Artists invest in community as they invest in their artistic practice, and many returns are relational in form. They take studios to be near other artists, develop relationships with near and far-flung collaborators, donate time and other resources to other artists and art institutions, and they open and nurture art institutions both informal and formal. They often do so with little hope of personal economic returns, and highlight relational and communitarian returns with few regrets. Artists work to create community - in some cases, stitching it from whole cloth. Megan, who with a collaborator runs a large project that costs them $\$ 26,000$ a year, sums up the relational impulse eloquently: 
“People used to say, 'Well, you guys must be so rich to do this!' And okay, I grew up poor, it is real money, but at the same time, other people who are like in the middle class or whatever spend that much on school tuition for their kid and nobody thinks twice about it. So I really resist the idea that this is somehow abnormal. Like I think it should be as normal as paying $\$ 26,000$ a year for your... instead of having a kid, we have our community."

Discomfort with the strictures of art as occupation takes active form in diverse accounts of the value of artistic practice, divergent valuations of that practice, and arguments about appropriate bases of value in the arts. The ideal types discussed here are not mutually exclusive or personal traits; artists use first one, then another type of account in patterned ways when they account for the value of artistic practice. Pecuniary and credentialing accounts are seen as legitimate both within and outside the art world, while vocationalist and relational accounts are legible primarily within the art world. Their uses give form to conflicts between traditional and occupational practice.

In the field of art, these conflicts are decidedly not between premarket "values" and monetary value. Artistic practice and the objects that often result were well commodified before the occupational turn, and within the field diverse values have long coexisted with market value, each mediating and modifying the other. Instead, conflicts over value in the art field today take the form of the insistence that specific bases of value in the arts be included in calculations of worth. These arguments point not to processes of decommodification (removal), but rather processes of disagreement and of revaluation. Vocationalist accounts, for example, do not aim to make artistic practice priceless; rather, they are used to mediate pricing either upwards or downwards depending on their deployment. Through arguments around the inclusion and 
exclusion of specific bases of value in the valuation of artistic practice, artists negotiate the conflicts between traditional and occupational practice. Some such accounts remain individuallevel phenomena, while others resonate within the community and become widely shared meanings, deployed regularly.

Relational accounts have become widely shared meanings only recently. The cracks between the structures of traditional and professional practice do not only allow for remnants of the meanings of traditional practice to leak through into contemporary rhetoric - they also leave room for the development and resonance of new accounts. Further study of the institutionalization of new and modified orders of worth will illuminate the ways that the disagreements individuals engage in can lead to structural and instrumental ramifications. In the next section, I consider why some meanings resonate and become widely shared meanings, while others do not.

\section{Resonant meanings}

Many potential bases of value are in any instance plausible and technically feasible, even within a single field. What explains the prominence of some, the absence of others? I have shown that distinctions between traditional practice and occupational practice are visible in contemporary art practice, and have outlined the ways that diverse accounts of value are used by individuals to express conflicts over such distinctions. Within the field of the arts, those bases of value that draw heavily on contemporary visions of traditional practice are most likely to achieve widespread resonance and become widely shared meanings.

It is contemporary ideas about traditional practice that hold sway, regardless of the true landscape of historical practice; some traditional practices and values, invisible to contemporary 
practitioners because they "make no sense" are preselected out of meaningful influence. While perhaps an infinite number of bases of value are plausible to account for a given practice, without a strong relationship to traditional practice (or, at least, contemporary visions of traditional practice) such plausible bases of value are unlikely to achieve widespread resonance among a community of practitioners, or to impact social action.

Varied accounts appear or even recur, but fail to achieve significant traction. A look at arguments over remuneration in the arts allows us to see a few such proposals. Artists occasionally point towards others working in arts institutions (sometimes curators but more often security guards and secretaries) or, farther afield, to other careers (plumbers, lawyers) to argue that, like these others, artists work many hours a week - or that, like lawyers and other professionals, artists are highly credentialed (e.g. Leijonhielm 1987). Despite the occasional recurrence of entirely plausible arguments such as these (artists do work many hours, and such effort could be the basis of value; artists are often highly trained, and that too could be incorporated in the valuation of practice), they have not come to be widely shared meanings in the art community, and are very rarely used by artists in accounting for the value of their own practice - in my interviews, I have not seen them used at all, and they are a vanishingly small minority of accounts I see in archival data. This type of account does not resonate with artists, and this lack of resonance can be explained by looking to artists' understandings of traditional practice - in particular, belief that quality has never been based on hours worked, and a strong belief that artistic practice has always been in crucial ways singular, not just like any other job.

Relational and vocationalist accounts of value are today widespread and widely shared among artists. Vocationalist accounts fit the widely held assumption that artists "have to" create, that they do it "for love, not money," that artists enjoy art work and that practice is its own reward. Relational accounts are new in the form they take today but they hearken back to long- 
held moral arguments about the beautiful and the good, and promote artistic practice for the benefit of society as a whole, and for both artists and audiences as citizens.

Those accounts of value without the support of traditional imaginaries are difficult to sustain. Without support in contemporary visions of traditional practice and its value, potential accounts are unlikely to become widespread. Despite the plausible viability of other types of accounts, two types - vocationalist and relational accounts - dominate in contemporary artists' conflicts over the valuation of their practices. Both draw on and fit within contemporary imaginaries of traditional practice, and are therefore culturally legible within the field. These two types of accounts are used to minimize, moderate, and criticize pecuniary and credentialing accounts in artists' narratives of the value of artistic practice.

\section{Discussion}

I have outlined a model of conflict over valuation in working life using contemporary artistic practice as a case. The process consists of three stages: as traditional practices undergo an occupational and then professional turn, tensions between old and new orders of worth come to be expressed in conflicts over valuation; diverse accounts of value proliferate; and finally, some accounts - those that draw on contemporary visions of traditional practice - achieve widespread resonance and become widely shared meanings.

My data suggest that future research on the simultaneous uses of multiple orders of worth and the accounts of those who successfully straddle diverse orders of worth will point towards new frameworks for thinking about value, identity, and practice in many fields. I find that, while some artists' accounts skew heavily toward one or another basis of value, the majority do not; different practices are accounted for in different ways, and artists can move both synchronically 
and temporally between frameworks. We might imagine what an art practice with only pecuniary accounts would look like to others: an artist with a clear sense of the risks of art practice and a strategy for maximizing returns on investment. It's this image of the artist that we're talking about when we say that speculation is taboo in the arts: the profit-maximizing artist playing the art game, bending to its rules, trying only to make a profit.

The soulless artist as speculator is only one of these caricatures standing at the boundary of the meaningful world of art practice. Vocationalism too has its limits: the artist who works only "for love, not money" - always either independently wealthy or garret-poor - represents within the art world unfair advantage either in patrimony or willingness to suffer. The Sunday painter - in this telling, often "retired", with a wink since she never worked - represents how far out of touch and out of step those who make art only for leisure can be with the rest of the community. Too much emphasis on credentialing is undeniably taboo; artists delegitimize practices they see as aiming towards commercial work or the tenure file - artists who do "the same old stuff over and over again", who make artwork only to "keep up their credentials." Relational accounts have been only recently widespread and legitimated in the art field and appear to be the least believable. Lofty assumptions about artists' intentions, most often drawn from the writings not of artists themselves but of critics and curators, are readily deployed within the field as arguments against the value of particular sorts of practices and specific artworks, as in this well-known piece of critical writing:

All relations that permit "dialogue" are automatically assumed to be democratic and therefore good. But what does "democracy" really mean in this context? [...] [his] intervention is considered good because it permits networking among a group of art dealers and like-minded art lovers, and because it evokes the atmosphere of a late-night 
bar. Everyone has a common interest in art, and the result is art-world gossip, exhibition reviews, and flirtation. Such communication is fine to an extent, but it is not in and of itself emblematic of "democracy." [...] [His] microtopia gives up on the idea of transformation in public culture and reduces its scope to the pleasures of a private group who identify with one another as gallery-goers. (Bishop 2004:65-69)

The caricatures that define the outer limits of relational accounts of value - the drunken men who simply aim to legitimate hanging out at the bar, the "politically active" young artist who fundamentally misunderstands the disadvantaged populations she uses in her practice, and the artist who points to dialogue with a "public" made up only of close friends - are less well known outside the art field than those who mark the outer limits of pecuniary, credentialing, and vocational accounts. But all of the caricatures discussed above live in the minds of most artists and structure their narratives and their criticisms. They serve as archetypical cautionary tales, shaping our understanding of appropriate goals, behavior, and accounts within the art community.

The money-grubbing artist-speculator is perhaps the best-known of these outside of the art community. But even here, pecuniary accounts exist alongside other frameworks, each mediating the other. Understanding how pecuniary frameworks coexist alongside other frameworks allows us to see why the caricature of the artist-as-speculator is both meaningful and absent from the real world of arts practice. Such caricatures define the unacceptable upper limit of each framework; the scheming artist-as-speculator and others live in the minds of most artists and mediate their narratives, though they cannot be seen to populate the real world.

\section{Conclusion}


In this paper I have shown the patterned ways in which the valuation of practice in a community of practice is contested. We should expect to see these processes of "decommensuration" in working life in any field where a rationalized understanding of activity as valuable - as an occupation, a profession - overlaps well enough with traditional practice to largely supplant it, while fitting poorly enough to allow for conflict between traditional and occupational bases of value. Stated differently, we would expect to see conflicts over value in those fields of human activity that we engaged in before economic life in capitalism made some of them into "jobs" - the care of young children and political work, for example. While the content of each step of the process outlined here - the divergent valuations, the historical imaginaries - would surely differ in other fields, the process would, I argue, look much the same.

Artmaking is a lot like the other things that have been done since we crawled from the sea and which life under capitalism has turned only partly into an occupation. We have always made things that look today like what we call art - similarly, we have always cared for children and others who required it, have always engaged in things that today we might call politics. Today, caring for children is work that can be done for free or for very high pay; you can learn to do it with advanced degrees or you can jump in headfirst. Some care for their own kin, others exclusively for others' children. There are many conflicting, even incommensurable visions of what "quality" child care looks like, and how to achieve it. Sometimes it's worth a lot, sometimes very little; sometimes it's for love, sometimes for money - as with many things that have undergone a contested and partial transformation with our move to money economies and the need for cash income. Politics can be done by volunteers with a $\mathrm{PhD}$ in political science or wellpaid advisors with backgrounds in advertising; there are few barriers to running for office and no limit to the demands on elected officials despite some full-timers being paid only in parking passes while others with fewer responsibilities earn good full-time salaries. Artists, like those 
who take care of children and engage in politics, commit to something that is not unambiguously worth their time. Paying attention to the ways that they account for the value of their practice can illuminate important processes of valuation - in working life as well as outside of it.

In fields like these, I suggest that we look for patterns in the accounts of practitioners, and pay attention to the ways that diverse bases of value are used by practitioners to promote distinct strategies of valuation. Such an analysis will highlight the importance of multiple pathways to value within fields, will show how valuation and revaluation is negotiated by individuals and institutions, and will show how disparate valuations are associated with divergent outcomes.

References

Almeling, Rene. 2007. “Selling Genes, Selling Gender: Egg Agencies, Sperm Banks, and the Medical Market in Genetic Material.” American Sociological Review 72(3):319-40.

Amos, Emma. 1968. "Oral History Interview with Emma Amos, 1968 October 3, Archives of American Art, Smithsonian Institution.”

Anteby, Michel. 2010. "Markets, Morals, and Practices of Trade: Jurisdictional Disputes in the U.S. Commerce in Cadavers.” Administrative Science Quarterly 55(4):606-38.

Art Workers Coalition. 1969. Documents 1. New York: Art Workers' Coalition.

Bandelj, Nina. 2012. "Relational Work and Economic Sociology.” Politics \& Society 40(2):175201.

Berman, Elizabeth Popp. 2006. "Before the Professional Project: Success and Failure at Creating an Organizational Representative for English Doctors." Theory and Society 35(2):157-91.

Biernacki, Richard. 1995. The Fabrication of Labor: Germany and Britain, 1640-1914. Berkeley: University of California Press.

Bishop, Claire. 2004. “Antagonism and Relational Aesthetics.” October -:51-79.

Bloch, Ernst and Mark Ritter. 1977. "Nonsynchronism and the Obligation to Its Dialectics." New German Critique (11):22-38. 
Boltanski, Luc and Laurent Thévenot. 2006. On Justification: Economies of Worth. Princeton: Princeton University Press.

Brante, Thomas. 2011. "Professions as Science-Based Occupations." Professions and Professionalism 1(1). Retrieved January 8, 2015 (https://journals.hioa.no/index.php/pp/article/view/147).

Bryan-Wilson, Julia. 2009. Art Workers: Radical Practice in the Vietnam War Era. Berkeley and Los Angeles: University of California Press.

Bunderson, J. Stuart and Jeffery A. Thompson. 2009. "The Call of the Wild: Zookeepers, Callings, and the Double-Edged Sword of Deeply Meaningful Work." Administrative Science Quarterly 54(1):32-57.

Caves, Richard E. 2003. "Contracts between Art and Commerce." The Journal of Economic Perspectives 17(2):73-84.

Clarke, John Clem. 1972. "Oral History Interview with John Clem Clarke, 1972 July 13, Archives of American Art, Smithsonian Institution."

Conner, Bruce. 1974. "Oral History Interview with Bruce Conner, 1974 Mar. 29, Archives of American Art, Smithsonian Institution."

Cowen, Tyler and Alexander Tabarrok. 2000. "An Economic Theory of Avant-Garde and Popular Art, or High and Low Culture." Southern Economic Journal 67(2):232-53.

Daniels, Arlene Kaplan. 1987. “Invisible Work.” Social Problems 34(5):403-15.

Espeland, Wendy Nelson and Michael Sauder. 2007. "Rankings and Reactivity: How Public Measures Recreate Social Worlds." American Journal of Sociology 113(1):1-40.

Espeland, Wendy Nelson and Mitchell L. Stevens. 1998. "Commensuration as a Social Process." Annual Review of Sociology 24:313-43.

Espeland, Wendy Nelson and Mitchell L. Stevens. 2008. "A Sociology of Quantification." European Journal of Sociology / Archives Européennes de Sociologie 49(03):401-36.

Evans, James A., Gideon Kunda, and Stephen R. Barley. 2004. "Beach Time, Bridge Time, and Billable Hours: The Temporal Structure of Technical Contracting." Administrative Science Quarterly 49(1):1-38.

Evetts, Julia. 2003. "The Construction of Professionalism in New and Existing Occupational Contexts: Promoting and Facilitating Occupational Change." International Journal of Sociology and Social Policy 23(4/5):22-35.

Faragher, Kristina. 2002. "Oral History Interview with Kristina Faragher, 2002 Nov. 12, Archives of American Art, Smithsonian Institution." 
Fine, Gary Alan. 2003. "Crafting Authenticity: The Validation of Identity in Self-Taught Art." Theory and Society 32(2):153-80.

Fischl, Richard Michael. 2004. “A Woman's World: What If Care Work Were Socialized and Police \& Fire Protection Left to Individual Families?” Buffalo Law Review 52:659-77.

Fourcade, Marion. 2011. "Cents and Sensibility: Economic Valuation and the Nature of 'Nature."” American Journal of Sociology 116(6):1721-77.

Goldberg, Chad Alan. 2007. Citizens and Paupers: Relief, Rights, and Race, from the Freedmen's Bureau to Workfare. Chicago: University of Chicago Press.

Gordon, Beverly. 2006. The Saturated World: Aesthetic Meaning, Intimate Objects, Women's Lives, 1890-1940. 1st ed. Knoxville: University of Tennessee Press.

Graw, Isabelle. 2010. High Price: Art Between the Market and Celebrity Culture. First Edition. Sternberg Press.

Hardy, K8. 2008. “Intro to W.A.G.E / Transcript of Speeches.” Retrieved May 11, 2010 (http://wageforwork.com/WAGE_RAGE_08.pdf).

Healy, Kieran. 2004. "Altruism as an Organizational Problem: The Case of Organ Procurement." American Sociological Review 69(3):387-404.

Heinich, Nathalie. 1996. The Glory of Van Gogh: An Anthropology of Admiration. Princeton, N.J.: Princeton University Press.

Hennion, Antoine. 2014. "'Blowing in the Wind'? ... A Response to the Author of 'Mastering the Jazz Standard: Sayings and Doings of Artistic Valuation." American Journal of Cultural Sociology 2(2):253-59.

Hochschild, Arlie Russell. 2003. The Second Shift. New York: Penguin.

Huault, Isabelle and Hélène Rainelli-Weiss. 2011. "A Market for Weather Risk? Conflicting Metrics, Attempts at Compromise, and Limits to Commensuration." Organization Studies 32(10):1395-1419.

Karpik, Lucien. 2010. Valuing the Unique: The Economics of Singularities. Princeton: Princeton University Press.

Kemp, Martin. 1997. Behind the Picture: Art and Evidence in the Italian Renaissance. New Haven, CT: Yale University Press.

Kopytoff, Igor. 1986. "The Cultural Biography of Things: Commoditization as Process.” Pp. 6491 in The Social Life of Things: Commodities in cultural perspective, edited by A. Appadurai. Cambridge: Cambridge University Press.

Larson, Magali Sarfatti. 1977. The Rise of Professionalism: A Sociological Analysis. Berkeley: University of California Press. 
Leijonhielm, Maria. 1987. “'Ingen Skillnad Mellan Rörmokare Och Konstnärer’ : Bisse Thofelt I Fejd Om Utställningsersättningen.” Pp. 4-5 in Konstnären (1985), vol. 1987:3.

Konstnären (1985) Stockholm : Konstnärernas riksorganisation (KRO), 1985-.

Lena, Jennifer C. and Danielle J. Lindemann. 2014. "Who Is an Artist? New Data for an Old Question." Poetics. Retrieved March 3, 2014 (http://www.sciencedirect.com/science/article/pii/S0304422X14000023).

Menger, Pierre-Michel. 2001. "Artists as Workers: Theoretical and Methodological Challenges." Poetics 28(4):241-54.

Messias, Deanne K. Hilfinger et al. 1997. "Defining and Redefining Work: Implications for Women's Health." Gender and Society 11(3):296-323.

Mondini-Ruiz, Franco. 2004. "Oral History Interview with Franco Mondini-Ruiz, 2004 July 7-8, Archives of American Art, Smithsonian Institution."

Montias, John Michael. 1989. Vermeer and His Milieu: A Web of Social History. Princeton, N.J.: Princeton University Press.

Plummer, Ken. 2002. Telling Sexual Stories: Power, Change and Social Worlds. Routledge.

Polanyi, Karl. 2001. The Great Transformation: The Political and Economic Origins of Our Time. 2nd Beacon Paperback ed. Boston, MA: Beacon Press.

Remington, Deborah. 1973. "Oral History Interview with Deborah Remington, 1973 May 29-July 19, Archives of American Art, Smithsonian Institution."

Rosso, Brent D., Kathryn H. Dekas, and Amy Wrzesniewski. 2010. "On the Meaning of Work: A Theoretical Integration and Review.” Research in Organizational Behavior 30:91-127.

Ryman, Robert. 1972. "Oral History Interview with Robert Ryman, 1972 October 13-November 7, Archives of American Art, Smithsonian Institution."

Saks, Mike. 2012. "Defining a Profession: The Role of Knowledge and Expertise." Professions and Professionalism 2(1). Retrieved January 8, 2015 (https://journals.hioa.no/index.php/pp/article/view/151).

Singerman, Howard. 1999. Art Subjects: Making Artists in the American University. Berkeley: University of California Press.

Snyder, Benjamin H. 2013. "From Vigilance to Busyness A Neo-Weberian Approach to Clock Time." Sociological Theory 31(3):243-66.

Spillman, Lyn. 1999. "Enriching Exchange: Cultural Dimensions of Markets.” American Journal of Economics and Sociology 58(4):1047-71.

Spillman, Lyn. 2012. Solidarity in Strategy: Making Business Meaningful in American Trade Associations. Chicago: The University of Chicago Press. 
Stark, David. 2009. The Sense of Dissonance: Accounts of Worth in Economic Life. Princeton: Princeton University Press.

Star, Susan Leigh and Anselm Strauss. 1999. "Layers of Silence, Arenas of Voice: The Ecology of Visible and Invisible Work." Computer Supported Cooperative Work 8(1-2):9-30.

Steiner, A. L. 2008. “Intro to W.A.G.E / Transcript of Speeches.” Retrieved May 11, 2010 (http://wageforwork.com/WAGE_RAGE_08.pdf).

Thompson, E. P. 1967. "Time, Work-Discipline, and Industrial Capitalism.” Past \& Present (38):56-97.

Timmermans, Stefan. 2005. "Suicide Determination and the Professional Authority of Medical Examiners." American Sociological Review 70(2):311-33.

Vasari, Giorgio. 1987. Lives of the Artists. London : New York: Penguin Books; Viking Penguin Inc.

Velthuis, Olav. 2005. Talking Prices: Symbolic Meanings of Prices on the Market for Contemporary Art. Princeton: Princeton University Press.

Weber, Max. 1978. Economy and Society: An Outline of Interpretive Sociology. Berkeley: University of California Press.

Weber, Max. 2001. The Protestant Ethic and the Spirit of Captalism. London: Routledge.

Wenger, Etienne. 1998. Communities of Practice: Learning, Meaning, and Identity. Cambridge, U.K. ; New York, N.Y: Cambridge University Press.

Wherry, Frederick F. 2006. "The Social Sources of Authenticity in Global Handicraft Markets Evidence from Northern Thailand.” Journal of Consumer Culture 6(1):5-32.

Wherry, Frederick F. 2008. "The Social Characterizations of Price: The Fool, the Faithful, the Frivolous, and the Frugal." Sociological Theory 26(4):363-79.

White, Harrison C. and Cynthia A. White. 1965. Canvases and Careers; Institutional Change in the French Painting World. New York: Wiley.

Wilensky, Harold L. 1964. “The Professionalization of Everyone?” The American Journal of Sociology 70(2):137-58.

Wiley, Kehinde. 2010. "Oral History Interview with Kehinde Wiley, 2010 September 29, Archives of American Art, Smithsonian Institution."

Wittkower, Rudolf and Margot Wittkower. 2007. Born under Saturn: The Character and Conduct of Artists : A Documented History from Antiquity to the French Revolution. New York: New York Review Books. 
Wrzesniewski, Amy and Jane E. Dutton. 2001. "Crafting a Job: Revisioning Employees as Active Crafters of Their Work." The Academy of Management Review 26(2):179-201.

Wrzesniewski, Amy, Clark McCauley, Paul Rozin, and Barry Schwartz. 1997. "Jobs, Careers, and Callings: People's Relations to Their Work." Journal of Research in Personality 31(1):21-33.

Zelizer, Viviana A. 2000. “The Purchase of Intimacy.” Law \& Social Inquiry 25(3):817-48.

Zelizer, Viviana A. Rotman. 2011. Economic Lives: How Culture Shapes the Economy. Princeton: Princeton University Press. 